\title{
Ikan Asing Invasif, Tantangan Keberlanjutan Biodiversitas Perairan
}

\author{
[Invasive Alien Spesies, sustainability aquatic biodiversity challenges] \\ Lenny S. Syafei, Dinno Sudinno
}

Jurusan Penyuluhan Perikanan, Sekolah Tinggi Perikanan

Jalan Cikaret No 2 Bogor 16001, Jawa Barat

Diterima: 14 September 2018; Disetujui: 30 November 2018

\begin{abstract}
Abstrak
Dikenal sebagai salah satu negara dengan mega-biodiversitas tertinggi, Indonesia juga tercatat memiliki kekayaan jenis ikan nomor tiga di dunia, setelah Brasil dan Cina. Sumber daya alam yang tidak dapat dipulih ini, berupa kekayaan jenis ikan; merupakan tanggung jawab bersama selaku bangsa. Karenanya, berbagai kondisi yang menekan perkembangan kekayaan jenis ikan asli, perlu mendapat perhatian yang serius. Satu diantaranya adalah kehadiran jenis ikan asing invasif yang masuk ke perairan tawar: danau dan sungai; baik disengaja/terprogram maupun tidak disengaja masuk kedalam perairan. Oleh karena itu, tulisan ini bertujuan untuk mengulas kondisi terkini ancaman dari jenis ikan asing invasif terhadap keberlanjutan biodiversitas perairan. Hasil dari tulisan ini adalah berbagai upaya yang dapat dilaksanakan untuk mempertahankan keberlanjutan biodiversitas perairan, khususnya perairan tawar.
\end{abstract}

Kata penting: ikan asing; ikan invasif; keberlanjutan; mega biodiversitas

\section{Abstract}

Known as one of the highest mega-biodiversity countries, Indonesia also noted as the third countries over the world which have fish spesies richness, after Brazil and China. This nonrenewable natural resouces, such as fish spesies richness; is our responsibility as a nation. Therefore, because of many various pressing development conditions of Indonesian native fish spesies, need to get serious attention. One of them is attendance invasive aline spesies that enters to aquatic freshwater, for example lake, reservoir and rivers; whether intentional or not enters to aquatic waters. That is why, the objectives of this paper is to review the latest threat conditions of alien invasive spesies presence to sustainability aquatic biodiversity. Result from this papers are various efforts that can be implemented to maintain the sustainability of aquatic biodiversity, especially in freshwater.

Keywords: alien spesies; invasive spesies; mega biodiversity; sustainability

Penulis korespondensi

Lenny S Syafei | lenny.syafei@gmail.com 


\section{PENDAHULUAN}

Beberapa waktu yang lalu, tepatnya pada akhir bulan Juni 2018; berbagai media di tanah air menuliskan tentang adanya ikan raksasa, Arapaima gigas yang tertangkap warga di Sungai Brantas, Jawa Timur. Menurut Froese \& Paully (2018), ikan Arapaima gigas ini adalah ikan asli Sungai Amazon Amerika Selatan dan termasuk International trade restricted (CITES II). Hal ini berarti bahwa jenis ikan ini hanya bisa dilalulintaskan antar negara dengan perijinan resmi yang menyatakan ketelusurannya termasuk F2 atau adalah hasil penangkaran. Dengan demikian, kalau sampai ikan ini tertangkap bebas di Sungai Berantas; kondisi ini perlu mendapat perhatian serius karena selain dikenal sebagai salah satu ikan air tawar terbesar di dunia, Arapaima gigas ini juga termasuk ikan predator; yang berpotensi sebagai ikan asing invasive di suatu ekosistem perairan yang didiami. Kehadiran ikan asing invasif itu sendiri dalam suatu ekosistem perairan sudah banyak menimbulkan permasalahan yang menyebabkan perubahan dan kerusakan habitat; bahkan bisa terjadi degradasi dan kerusakan genetik dari stok inang oleh hibridisasi, dan penyebab terganggunya spesies asli. Lebih lanjut dijelaskan, bahwa biaya ini sudah dikeluarkan sejak tahun 1956 dan masih akan terus dianggarkan karena spesies ini menyebar dengan cepat, serta secara invasif merusak lingkungan.

Informasi yang sama menurut catatan dari masuknya spesies eksotik di suatu perairan, seperti yang dilaporkan Fukumoto et al. (2015) terjadi pada perairan Katsura River di Jepang yang merupakan habitat alami ikan Japanese Giant Salamander (Andrias japonicus); kemudian ditebar ikan Chinese Giant Salamader (Andrias davidiamus); kondisi yang terjadi kemudian adalah hibridisasi dari kedua spesies ini. Dengan menggunakan analisa Environmental DNA, diketahui sudah mulai terdapat penyebaran ikan hibrid salamander pada dua sungai lainnya di Jepang.

Dua negara dengan kepemilikan mega-biodiversity tertinggi di dunia, yaitu: Brazil dan Cina, juga menghawatirkan keberadaan non-native spesies, ikan asing invasif. Pelicice et al. (2012) menyatakan bahwa keberadaan dua spesies ikan asing invasif di Brazil, yaitu: ikan mas dan ikan nila secara masif pada kegiatan budidaya karamba jaring apung sebagai sarana pengembangan ekonomi: ternyata telah merusak keanekaragaman hayati ikan asli, ekosistem, dan kualitas lingkungan secara meluas di Brazil. Sanches et al. (2011) menambahkan bahwa selama lebih dari 50 tahun ikan nila di Brazil telah menjadi spesies asing invasif yang menekan pertumbuhan populasi ikan asli 
Lepomis miniatus, sunfish. Permasalahan yang sama tentang kehadiran ikan asing di negara Cina, khususnya di Provinsi Yunan menekan perkembangan populasi ikan-ikan asli setempat.

Di Indonesia, yang tercatat sebagai negara mega-biodiversitas nomor tiga di dunia, memiliki 1.193 spesies ikan dengan sekitar 120 spesies ikan endemik (Froese \& Pauly 2013 dalam Syafei 2017). Lebih jauh dijelaskan Syafei (2017) bahwa ditinjau dari sudut iktiogeografis, ikan air tawar di Indonesia mendiami tiga daerah sebaran geografis (Paparan Sunda, Daerah Wallace, dan Paparan Sahul) yang dibatasi oleh dua garis maya: Garis Wallace dan Garis Weber. Masing-masing daerah sebaran tersebut memiliki ciri khas spesies tersendiri. Banyak data menyebutkan hilangnya ikan endemik suatu perairan karena adanya introduksi yang baik sengaja maupun tidak, salah satu contoh klasik adalah makin sulitnya ditemukan ikan batak (Neolissochilus thienemanni) di Danau Toba, Sumatera Utara.

Permasalahan berkurangnya dan bahkan punahnya spesies ikan endemik dan ikan asli di berbagai belahan dunia; ditengarai akan mengganggu keberlanjutan biodiversitas perairan. Karena itu, diperlukan berbagai upaya secara bersama agar kekayaan alam ini dapat terjaga guna mendukung kehidupan yang ramah dengan alam. Sebagai salah satu upaya, tulisan ini disajikan untuk menginformasikan langkah-langkah yang secara bersama perlu dilakukan, dengan maksud agar keberlanjutan biodiversitas perairan tetap merupakan keberpihakan kita. Metoda yang dilakukan dalam kajian ini adalah penelusuran pustaka yang mendukung substansi tulisan.

\section{IKAN ENDEMIK, IKAN ASLI DAN IKAN ASING}

Ikan endemik adalah spesies ikan yang hanya berada di suatu perairan dan tidak terdapat di perairan lainnya. Di Indonesia, terdapat Ikan endemik mulai dari Pulau Sumatera sampai dengan Pulau Papua.

Ikan endemik yang terdapat di Pulau Sumatera, tercatat antara lain: di Provinsi Nanggro Aceh Darussalam (NAD) terdapat ikan keperas (Poropuntius tawarensis) dan depik (Rasbora tawarensis) yang hidup di Danau Laut Tawar yang terletak di Dataran Tinggi Gayo, Kabupaten Aceh Tengah, Aceh (Muchlisin et al. 2010; Giacalone et al. 2010). Tampilan kedua ikan endemik Danau Laut Tawar, Aceh dapat dilihat pada Gambar 1. Ikan endemik dari Provinsi Sumatera Utara, ssalah satunya adalah ikan batak (Neolissochilus thienemanni) yang hanya mampu hidup dan berkembang di Danau Toba, Sumatera Utara dan sejumlah 


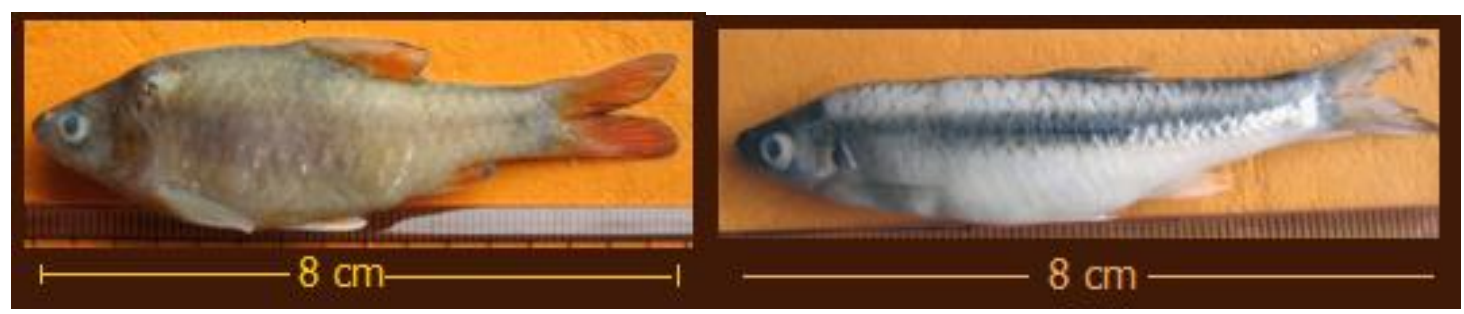

(a) (b)

Gambar 1. Ikan endemik dari Danau Laut Tawar, Aceh:

(a) Puntius tawarensis (b) Rasbora tawarensis

(sumber foto; Muchlisin 2010)

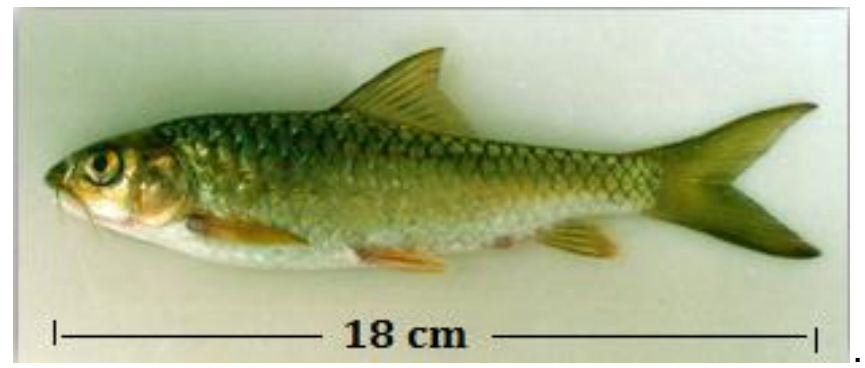

Gambar 2. Ikan endemik dari Danau Toba, Sumatera Utara Ikan Batak, Neolissochilus thienemanni (sumber foto; Thomas 1990 dalam Froese \& Pauly 2018)

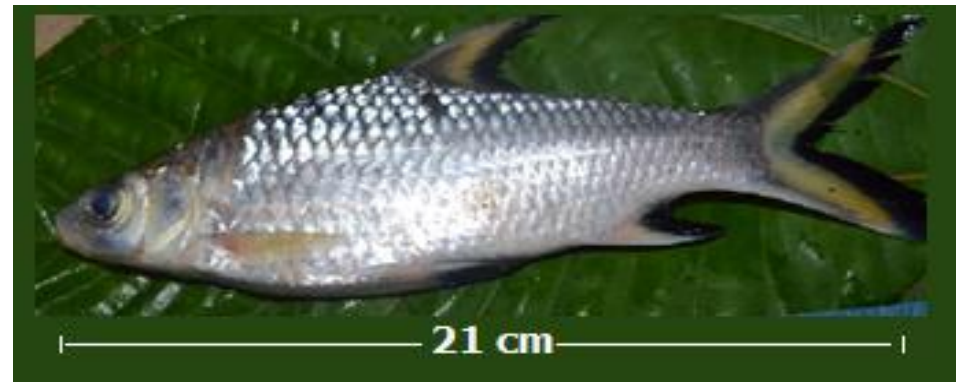

Gambar 3. Ikan tergolong genting dari perairan Hutan Harapan Jambi Ikan Ridiangus (Balantiocheilos melanopterus)

(sumber foto; Sukmono 2013)

anak sungai yang bermuara ke Danau Toba

Untuk Provinsi Jambi, Sukmono et. al. (2017), mencatat tiga spesies hampir terancam punah, yaitu: ikan lais kaca (Kryptoperus minor), ikan parang-parang bengkok (Macrochirichtys marcrochirus), dan ikan sepat mutiara (Trichopodus leerii) 3. Serta satu spesies tergolong genting, yaitu: ikan ridiangus (Balantiocheilos melanop-terus) yang terdapat di perairan Hutan Harapan di Jambi dapat dilihat pada Gambar 3. 


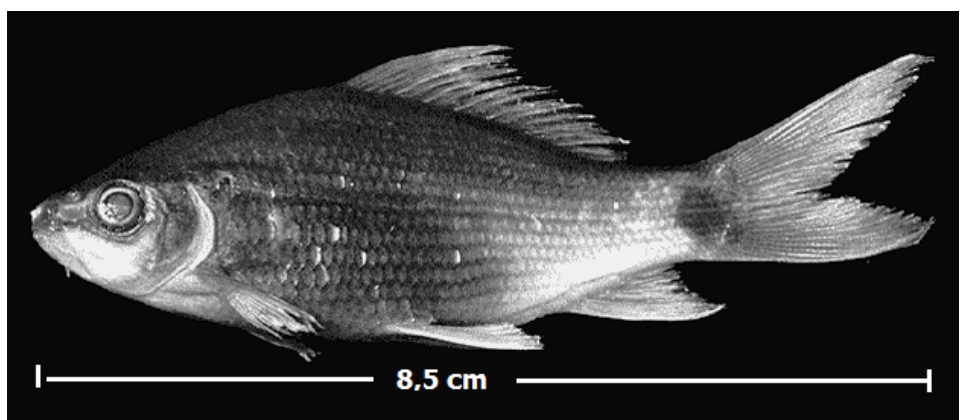

Gambar 4. Ikan endemik dari perairan Sungai Kapuas, Kalimantan Barat Osteochilus borneensis

(sumber foto: Robert 1967 dalam Froese \& Pauly 2018)

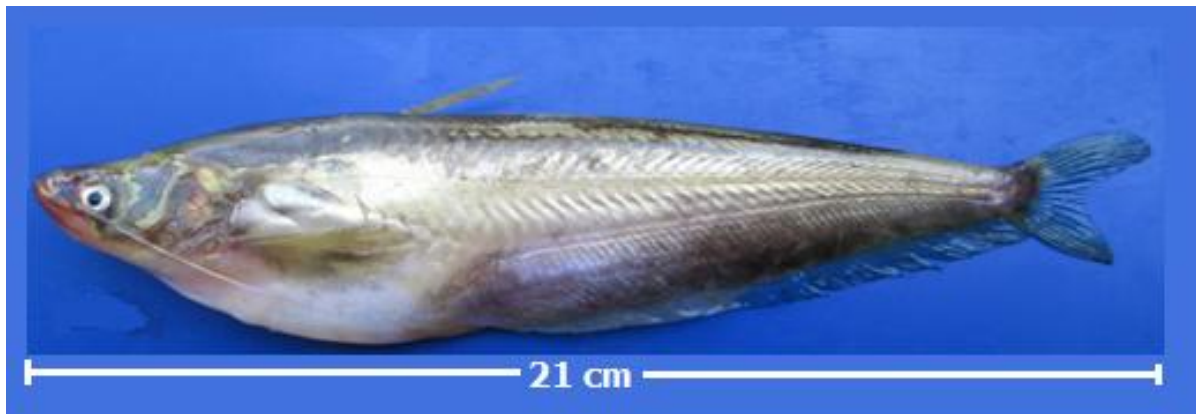

Gambar 5. Ikan endemik dari perairan Sungai Mahakam, Kalimantan Timur Ikan Lais Lempok (Ompok miostoma)

(sumber foto: Jusmaldi et. al.. 2017)

Ikan endemik yang terdapat di

Pulau Kalimantan, antara lain di

Provinsi Kalimantan Barat terdapat spesies Osteochilus borneensis yang ditemukan oleh Robert (1976 dalam Froese \& Pauly 2018) di Sungai Kapuas, yang dapat dilihat pada Gambar 4. Sedangkan dari Kalimantan Timur, seperti dilaporkan oleh Jusmaldi et. al.. (2017) terdapat spesies endemik, yaitu ikan lais lempok (Ompok miostoma) dari perairan Sungai Mahakam, sebagaimana terlihat pada Gambar 5.

Ikan endemik yang terdapat di Pulau Sulawesi, antara lain ikan butini
(Glossogobius matanensis) dari perairan Danau Towuti, sebagaimana hasil penelitian Mamangkay \& Nasution (2012) yang terlihat pada Gambar 6 . Catatan pelengkap kehadiran ikan endemik di perairan Danau Towuti yang tercatat sebagai danau terdalam nomor tujuh di dunia ini, dikemukakan pada tahun 1993 masih terdapar 52 spesies ikan endemik di peraiaran Danau Towuti (Kottelat et al. 1993); dan berkurang hampir setengahnya pada 10 tahun kemudian, yaitu pada tahun 2003 tercatat kurang dari 28 spesies ikan endemik yang tersisa (Wirjoatmojo et al. 


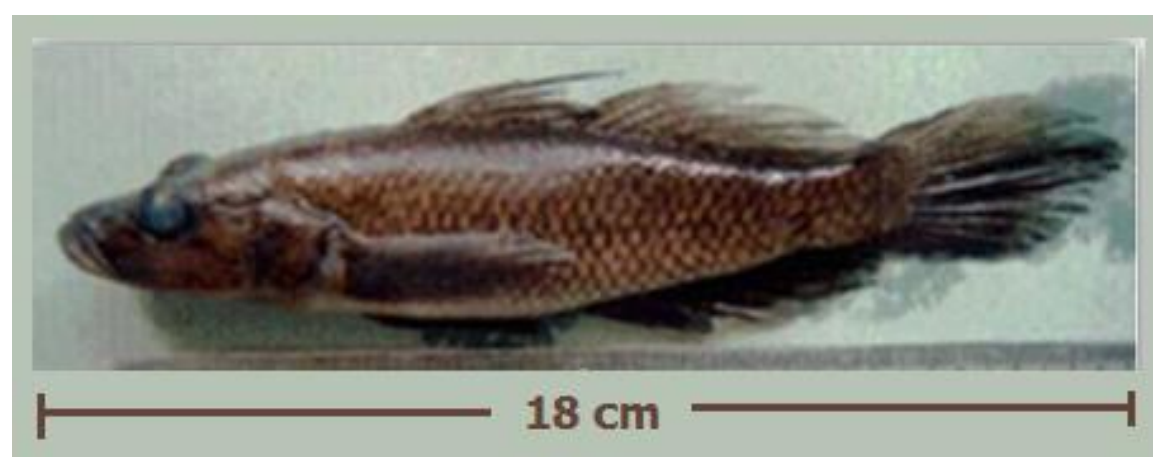

Gambar 6. Ikan endemik dari perairan Danau Towuti Sulawesi Selatan Ikan Butini (Glossogobius matanensis) (sumber foto: Mamangkey \& Nasution 2012)

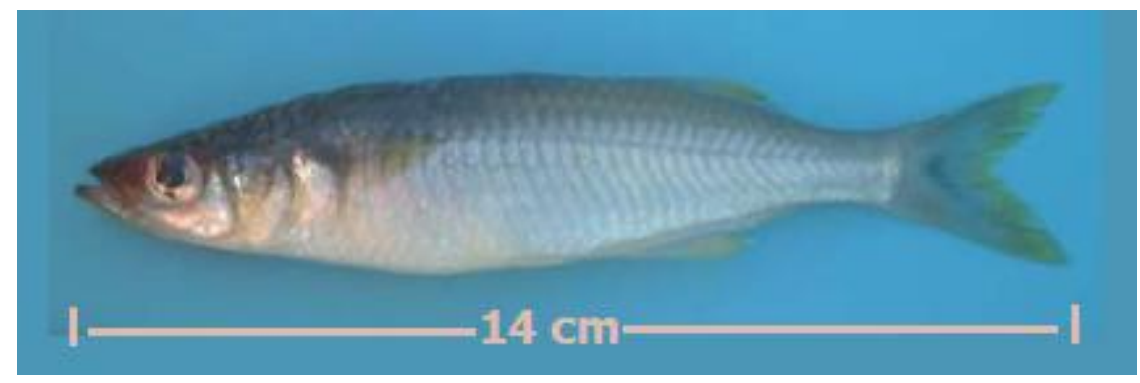

Gambar 7. Ikan endemik dari perairan Danau Towuti, Sulawesi Selatan Ikan Bonti-bonti (Paratherina striata Aurich) (sumber foto: Nasution 2008)

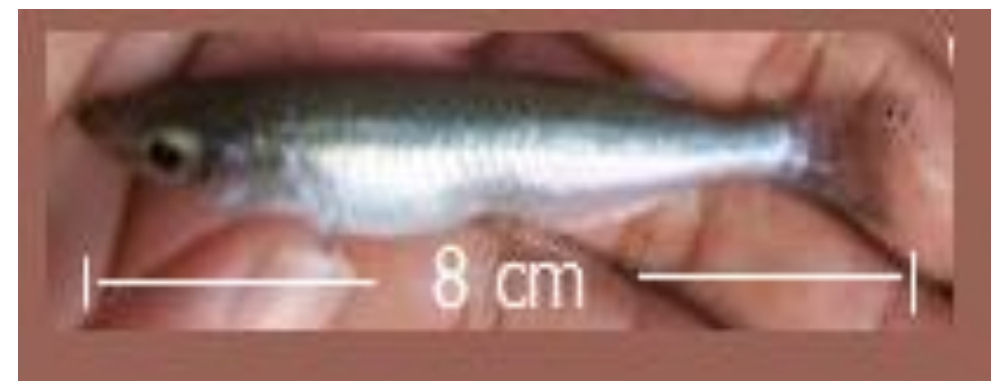

Gambar 8. Ikan endemik dari perairan Danau Poso, Sulawesi Tengah Ikan Rono (Xenopoecilus oophorus)

(sumber foto: Rahardjo 2016)

2003). Salah satunya adalah ikan bontibonti (Paratherina striata Aurich) yang dapat dilihat pada Gambar 7.

Masih di Pulau Sulawesi, tepatnya di perairan Danau Poso, Provinsi Sulawesi Tengah; Rahardjo (2016) mencatat ikan rono (Xenopoecilus oophorus) sebagai salah satu ikan endemik di perairan Danau Poso yang dapat dilihat pada Gambar 8. Lebih lanjut dijelaskan Rahardjo (2016) bahwa pada tahun 2016 masih tercatat sembilan 


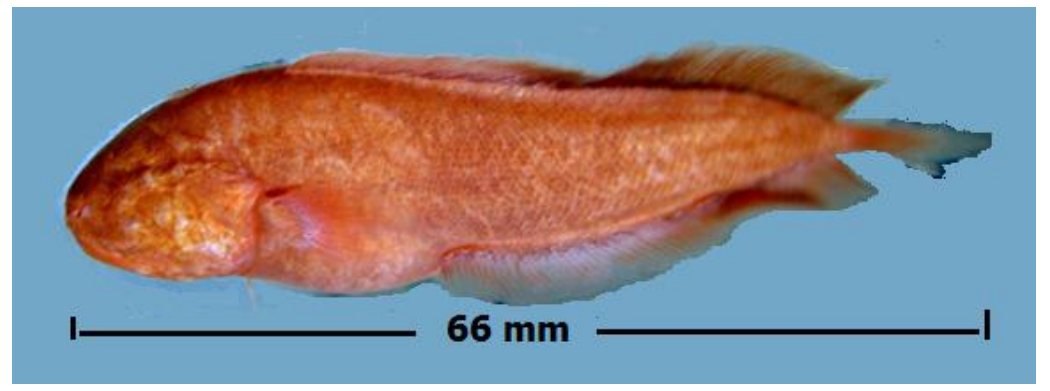

Gambar 9. Ikan endemik spesies baru dari perairan gua-gua payau

Pulau Muna, Sulawesi Tenggara:

Ikan Buta dari Muna (Diancistrus typhlops)

(sumber foto: Nielsen et al. 2009)

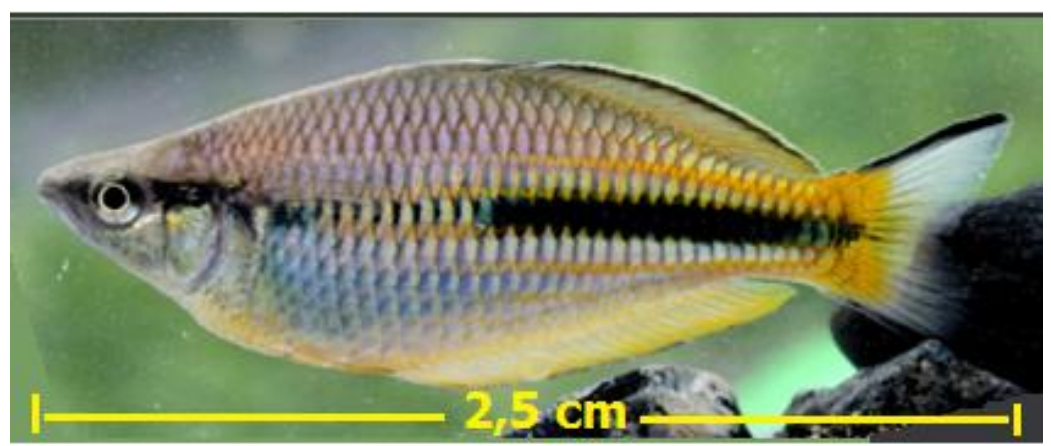

Gambar 10. Ikan endemik dari perairan Sungai Prafi, Manokwari, Papua Ikan Pelangi Arfak (Melanotaenia arfakensis) (sumber foto: dokumentasi pribadi E. Manangkalangi)

spesies ikan endemik penghuni Danau Poso, sedangkan satu spesies ikan endemik Danau Poso telah dinyatakan punah, yaitu: Adrianichthys kruyti Weber 1913. Selain itu, Neilsen et al. (2009) melaporkan ditemukannya spesies baru di perairan payau pada gua-gua di Pulau Muna, Sulawesi Tenggara, yaitu ikan buta dari Pulau Muna (Diancistrus typhlops), seperti terlihat pada Gambar 9.

Ikan endemik yang terdapat di Pulau Papua antara lain ikan pelangi arfak (Melanotaenia arfakensis Allen 1990) yang terdapat di sepanjang Sungai
Prafi, Manokwari, di bagian timur laut Kepala Burung (Vogelkop), Pulau Papua. Tampilan ikan pelangi arfak, atau nama lokal setempat disebut ikan "Anggicak" dalam Bahasa Suku Arfak, dapat dilihar pada Gambar 10, yang merupakan dokumentasi pribadi Manangkalangi. Selain itu, ditemukan ikan endemik pelangi korumoi (Melanotaenia parva) dari perairan Danau Kurumoi Kabupaten Sorong, Provinsi papua Barat (Allen et al. 2008), sebagaimana terlihat pada Gambar 11.

Ikan endemik yang terdapat di Kepulauan Maluku, antara lain ikan hiu 


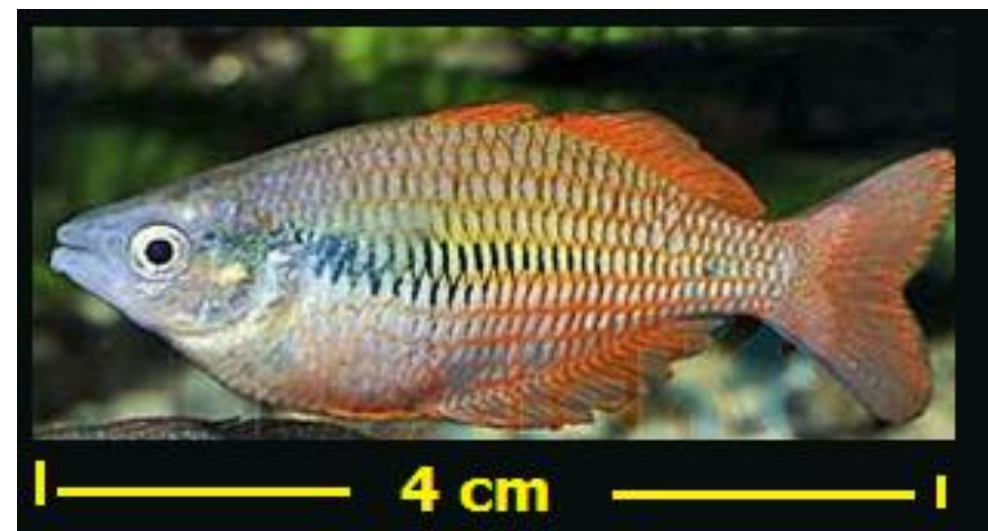

Gambar 11. Ikan endemik dari perairan Danau Karamoi, Papua Barat Ikan Pelangi Karamoi (Melanotaenia parva)

(sumber foto:Allen et al. 2008)

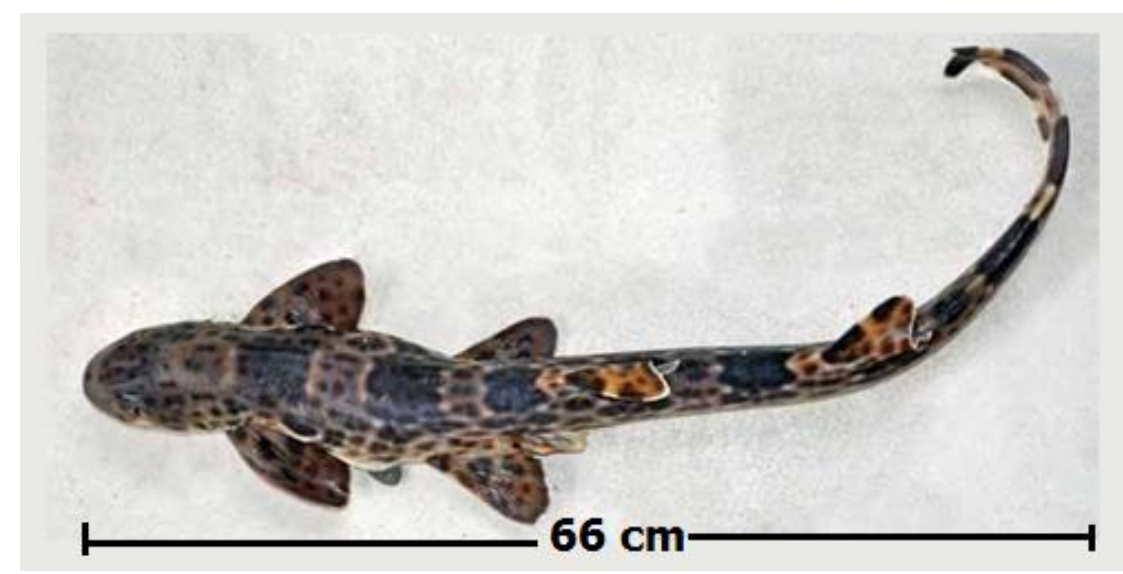

Gambar 12. Ikan endemik dari perairan laut bagian selatan Ternate, Halmahera Ikan Hiu Berjalan (Hemiscyllium halmahera)

(sumber foto:Allen et al. 2013)

berjalan Halmahera (Hemiscyllium halmahera Allen \& Erdmann 2013) yang terdapat perairan bagian selatan Ternate, Halmahera Utara, Provinsi Maluku Utara (Allen et al. 2013). Morfologi iakn hiu berjalan halmahera ini dapat dilihat pada Gambar 12.

Ikan asli adalah spesies ikan yang pada awalnya berada di suatu perairan, tetapi dapat bertumbuh dan berkembang di perairan lain dalam wilayah yang terbatas. Atau dapat dikatakan: ikan asli adalah ikan endemik yang ternyata bisa hidup dan berkembang di perairan lain. Salah satu contoh ikan endemik yang berubah menjadi ikan asli adalah ikan bilih (Mystacoleucus padangensis) dari Danau Singkarak di Sumatera Barat; yang sejak tahun 2003 pada saat ditebar di Danau Toba dan ternyata bertumbuh dan berkembang dengan baik, maka sejak itu ikan bilih digolongkan sebagai 
ikan asli Danau Singkarak. Menurut hasil kajian Kartamihardja (2012), tercatat ikan bilih di Danau Toba berkembang dengan pesat bahkan mendominasi, sejak tahun 2005. Ikan asli Danau Toba, antara lain adalah ikan Tambra/Kancra, Tor soro. Ikan asli Sungai kampar Kiri antara lain adalah ikan Selais, Ompok hypophthalmus (Bleeker)(Simanjuntak et. al.. 2017). Di Pulau Jawa, Kabupaten Kuningan terdapat ikan asli yaitu ikan Dewa atau ikan Kancra Domas (Tor douronensis) dan termasuk ikan yang dilindungi oleh masyarakat setempat serta dilarang untuk dimakan (Sjafei et. al. 2001). Pada Perairan Pulau Kalimantan, terdapat banyak ikan asli, antara lain ikan hias Botia (Chromobotia macracanthus Bleeker). Ikan hias Botia ini memiliki warna kulit belang hitam tiga baris diatas warna dasar tumbuhnya yang berwarna kuning jingga. Karena warna tubuh Botia cukup eksotik, maka potensi untuk diekspor sebagai ikan hias sangat besar. Pada perairan Pulau Sulawesi terdapat beberapa ikan asli antara lain ikan Sidat (Anguilla celebensesis) yang terdapat pada muara Sungai Poigar dan Sungai Poso di Sulawesi Barat (Arai et al. 2003).

Ikan asing adalah spesies ikan yang berasal dari luar perairan wilayah Indonesia. Kehadiran spesies ikan asing ini terjadi melalui beberapa cara, antara lain: diprogramkan untuk peningkatan produksi perikanan, khususnya perikanan budidaya; dibawa oleh para pencinta ikan hias maupun ikan konsumsi; bahkan ada juga yang tidak sengaja terbawa ke perairan Indonesia dalam berbagai cara.

Ikan asing yang berada di perairan Indonesia, dapat dikelompokkan dalam dua bagian, yaitu ikan asing yang tidak mengganggu populasi ikan endemik dan ikan asli dalam suatu ekosistem perairan; dan ikan asing yang mengganggu populasi ikan-ikan endemik dan ikan asli dalam ekosistem perairan yang sebelumnya tidak terdapat spesies ikan asing. Katagori ikan asing yang mengganggu, disebut ikan asing invasif. Umumnya ikan asing yang tidak mengganggu, bahkan mampu meningkatkan total produksi perikanan, antara lain ikan patin (Pangasiadon hypothalmus), ikan mas (Cyprinus carpio L.), ikan nila (Oreochromis niloticus); dipandang tidak merugikan sektor perikanan Indonesia. Termasuk berbagai spesies ikan hias asing yang meningkatkan produksi dan bisnis ikan hias Indonesia, antara lain: ikan cupang (Betta splendens), ikan koki (Carassius auratus) dan ikan koi (Cyprinus carpio). Sebagian besar daftar spesies ikan asing yang masuk ke perairan Indonesia dapat dilihat pada Tabel 1. 
Tabel 1. Jenis spesies asing yang masuk ke perairan Indonesia

\begin{tabular}{clcc}
\hline No & \multicolumn{1}{c}{ Nama Ilmiah } & Nama Inggris & Nama Indonesia \\
\hline 1. & Aequidens pulcher & Blue acara & Golosom \\
2. & Amphilophus citrinellus & Red devil & Oskar \\
3. & Symphysodon discus & Red discus & Discus \\
4. & Carassius auratus & Goldfish & Mas koki \\
5. & Ctenopharyngodon idella & Grass carp & Koan \\
6. & Clarias gariepinus & North African catfish & Lele dumbo \\
7. & Cyprinus carpio & Common carp & Mas \\
8. & Oreochromis mossambicus & Mozambique tilapia & Mujair \\
9. & Oreochromis niloticus & Nile tilapia & Nila \\
10. & Pangasianodon hypothalmus & Catfish & Patin \\
11. & Poecilia reticulata & Guppy & Seribu \\
12. & Parachromis managuensis & Jaguar guapote & Manila gift \\
13. & Trichogaster pectoralis & Snakeskin gourami & Sepat siam \\
\hline
\end{tabular}

\section{UPAYA PENGENDALIAN IKAN ASING INVASIF}

Uraian diatas memperlihatkan bahwa kehadiran ikan asing invasif akan merugikan ekosistem perairan dalam dua hal, yaitu: (1) sebagai pesaing relung makanan dan habitat terhadap ikan asli, bahkan sering terjadi merupakan predator bagi ikan asli. Karena ikan asing invasif ini menjadi pemangsa ikan asli dan ikan endemik; (2) sebagai inang/pembawa berbagai penyakit yang sebelumnya tidak terdapat dalam ekosistem perairan yang merupakan habitat ikan asli bahkan ikan endemik. Kedua hal ini seringkali mengubah komposisi spesies dan struktur komunitas ikan, mendominasi dan menyingkirkan ikan asli dan ikan endemik.
Untuk mengetahui karakteristik suatu jenis ikan termasuk spesies ikan asing yang invasif, beberapa kondisi pada ekosistem dapat diamati bila: (1) kelimpahan spesies introduksi yang baru ditebar ternyata sangat tinggi, khususnya tingkat fekunditas tergolong tinggi; (2) masa atau waktu yang dibutuhkan untuk regenerasi relatif singkat; (3) memiliki kemampuan menguasai beragam habitat, atau dengan kata lain kisaran makanan sangat luas; serta (4) dilihat dari sisi keragaman genetik tergolong sangat tinggi. Dengan karakteristik seperti ini, maka sangat jelas ikan asing invasif akan berdampak menjadi pesaing spesies asli dan endemik yang mengisi relung ekologis yang sama, akibat lanjut adalah mengganggu jejaring makanan 
dan mengurangi keanekaragaman hayati. Pada akhirnya, ikan asing invasif akan mengancam populasi ikan asli dan ikan endemik.

Cukup banyak catatan yang memperlihatan kerugian kehadiran ikan asing invasif yang membawa penyakit baik yang terjadi di Indonesia maupun di manca negara. Di Indonesia, tercatat serangan wabah Koi Herpes Virus (KHV) yang terdeteksi mulai awal bulan Maret tahun 2002, dan menimbulan kerugian finansial yang cukup besar akibat kematian total ikan koi dan ikan mas yang dibudidayakan hampir $90 \%$. Sejak serangan KHV yang mewabah tersebut, sampai dengan saat ini pengendalian dan pernyataan bahwa Indonesia bebas KHV belum dapat diwujudkan; dan tetap masih menjadi pekerjaan rumah yang tidak kunjung rampung. Sudah tidak dapat terhitung lagi berapa kerugian finansial yang dibebankan kepada Indonesia, sudah banyak pemikiran dan waktu yang dicurahkan oleh para ahli di bidangnya untuk menangani hal ini; tetapi tetap saja informasi adanya serangan KHV diberbagai lokasi budidaya masih tetap dilaporkan. Sejak menjadi epedemi KHV di Indonesia dari tahun 2002 sampai dengan tahun 2018, terus menerus dilakukan berbagai cara untuk menanggulangi $\mathrm{KHV}$, baik melalui pengobatan massal, treatmen perairan budidaya, aplikasi vaksine sampai dengan CKIB, tetapi hasilnya belum memuaskan (Mulyani et. al.. 2011). Hasil Pemantauan Hama dan Penyakit Ikan Karantina (HPIK) yang dilaksanakan oleh Stasiun KIPM Yogyakarta selama 10 tahun terakhir menunjukkan bahwa budidaya ikan di Daerah Istimewa Yogyakarta sering menghadapi serangan HPIK, satu diantaranya serangan KHV (Anonimus 2017). Dari data ilmiah yang ada diketahui bahwa ikan-ikan cyprinid seperti ikan mas dan ikan koi bukan ikan asli Indonesia. Jenis ikan ini adalah ikan asing yang berasal dari Eropah dan Asia, menurut Froese \& Pauly (2018), spesies Cyprinus carpio adalah spesies original dari negara Eropah. Bahkan kajian Chiba et al. (1966) serta Kirpichnikov (1981) dalam Zhou at al. (2003), menyebutkan ikan mas telah dikenal di Eropah sejak zaman Yunani dan Romawi Kuno; dan menambahkan bahwa ikan mas ditemukan di Eropah, khusus di Sungai Danube, Jerman pada abad ke-17 dan abad 18. Penjelasan lebih rinci dikemukakan oleh Zhou at al. (2003), melalui asesment dengan analisa mitochondria-DNA diperoleh hasil bahwa secara ilmiah ditetapkan subspesies Cyprinus carpio carpio adalah subspesies ikan mas asli dari Eropah: subspesies Cyprinus carpio haematopterus adalah subspesies ikan mas asli dari Asia. Kecuali untuk 
subspesies Cyprinus carpio chlilia adalah subspesies endemik ikan mas dari danau di wilayah Yunan, Cina; serta subspesies Cyprinus carpio rubrofucus adalah subspesies endemik ikan mas dari ekositem perairan di wilayah Cina Selatan (Wu Xianwen et al. 1977 dalam Zhou at al. 2003).

Pada belahan dunia lainnya, serangan penyakit akibat introduksi ikan asing, tercatat juga di USA; pada tahun 1958 parasit Myxobolus cerebralis menyerang juvenile ikan trout dan ikan salmon yang diperuntukan bagi kegiatan usaha bisnis olahraga pancing; sehingga bisnis ini mengalami kerugian (Hoffman 2011).

Jenis ikan asing invasif sebagai pesaing relung makanan dan habitat terhadap ikan asli, dapat dilihat dengan semakin sulitnya diperoleh ikan lele lokal (Clarias batrachus). Kajian Diani (2013) dengan menggunakan analisis penanda genetik berbasis RAPD-PCR, menyatakan bahwa saat ini di Indonesia terdapat tiga kelompok besar lele, yaitu: lele lokal, lele dumbo dan lele sangkuriang. Sebagai ikan konsumsi, ikan lele yang diharapkan adalah yang tumbuh dengan cepat, tahan penyakit dan kemampuan regenerasi, misal fekunditas lebih tinggi; dan ternyata dalam beberapa hal diatas, lele lokal tidak bisa bersaing; sehingga tidak menjadi pilihan untuk dikembangkan.
Pada giliran berikutnya, dapat diduga spesies ikan lele lokal akan mendekati punah.

Dengan berbagai kerugian diatas, maka diperlukan langkah-langkah pencegahan dan pengendalian kehadiran atau introduksi ikan-ikan asing tanpa dicermati keuntungan dan kerugian dari kegiatan tersebut; sebagaimana dijabarkan pada digram alir upaya pengendalian spesies ikan invasif dalam Gambar 13. Tahapan pencegahan yang perlu dilakukan adalah membangun penyamaan persepsi dari semua pemangku kebijakan, pelaku kegiatan perikanan, dan masyarakat perikanan tentang diperlukannya sisi pencegahan. Karena akan lebih mudah dibanding mengendalikan spesies ikan asing invasif yang disengaja maupun tidak disengaja; dan ternyata sudah masuk ke dalam suatu ekosistem perairan. Setelah melakukan penyamaan persepsi dengan semua pemangku kepentingan, maka simultan dengan kegiatan tersebut adalah menginformasikan berbagai spesies ikan yang yang digolongkan kedalam kelompok ikan asing invasif, salah satunya adalah Arapaima gigas. Bila ternyata akan diputuskan adanya kegiatan introduksi ikan asing, karena berbagai alasan khususnya alasan ekonomis; maka perlu dicermati dengan baik tentang aspek-aspek biologisnya. 


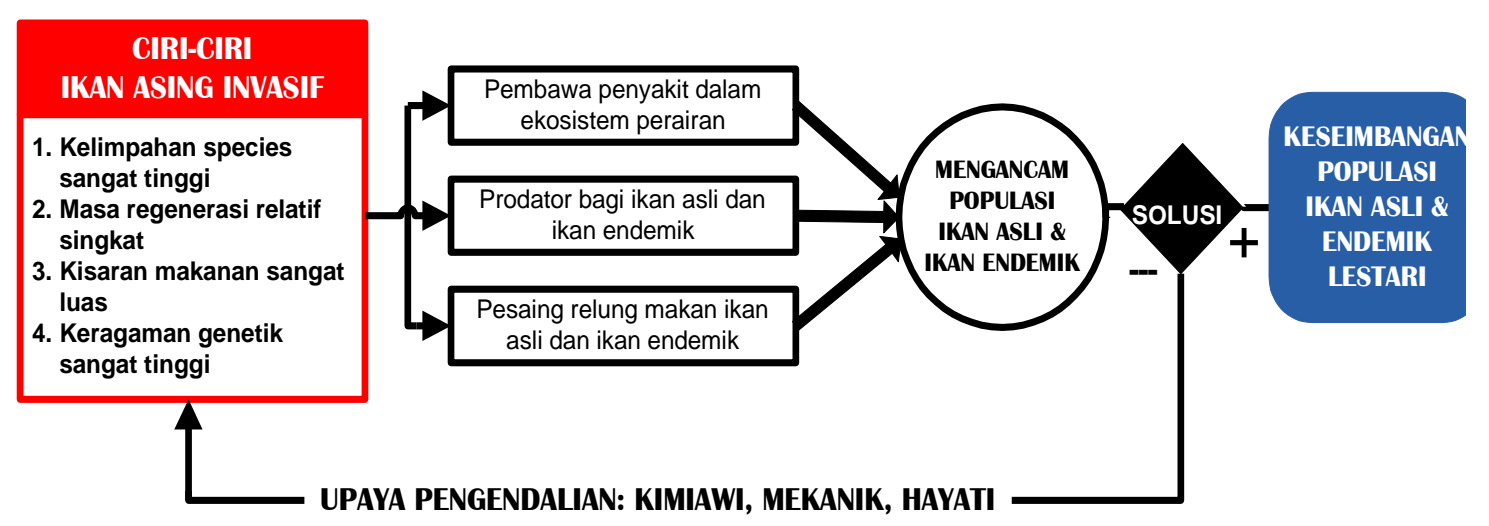

Gambar 13. Diagram alir upaya pengendalian kehadiran ikan asing invasif

Kebiasaan makan dan makanannya, predator atau bukan, tingkat kesehatan ikan/ pembawa parasit atau virus. Setelah hal-hal diatas dicermati dengan baik, dan dapat dinyatakan tidak bermasalah untuk ditebar atau diintroduksi ke perairan umum, maka ikan asing dapat diterima. Untuk hal ini, dari sisi pemerintah telah dikeluarkan Keputusan Menteri Kelautan dan Perikanan Republik Indonesia Nomor KEP.58/MEN/2016 tentang Status Area Tidak Bebas Penyakit Ikan Karantina di Wilayah Republik Indonesia (Anonimus 2016).

Bilamana ikan asing sudah masuk ke ekosistem perairan Indonesia, maka langkah yang perlu dilakukan adalah pengendalian. Langkah pertama adalah mengidentifikasi apakah ikan asing yang terdapat dalam perairan adalah invasif atau bukan. Perlu dibangun suatu Standar Operasional Prosedur yang baku, sehingga memudahkan identifikasi di lapangan. Pengendalian dapat dilakukan dengan berbagai cara, sebagai berikut:

a. Pengendalian kimiawi (menggunakan pestisida, herbisida, fungisida). Cara ini cukup efektif, akan tetapi dapat ikut mematikan spesies non-invasif lainnya; bahkan bila tidak selektif memilih bahan kimiawi dapat menimbulkan masalah apabila ternyata mengganggu kesehatan manusia;

b. Pengendalian mekanik (pemindahan fisik spesies invasif atau mengubah kondisi habitat). Tindakan ini sering berhasil/sukses tetapi bisa mahal dan membutuhkan tenaga kerja yang banyak;

c. Pengendalian hayati (introduksi musuh alami- predator atau parasit). Perlakuan ini lebih memperhatikan pelestarian lingkungan.

Bila ketiga langkah diatas masih juga belum berhasil, maka perlu dilakukan kegiatan 'penyingkiran'. Kegiatan ini diawali dengan deteksi dini, 
kemudian melakukan tanggap cepat untuk menyingkirkan spesies invasif; serta perlu melakukan pemantauan berkala secara rutin. Diakhir semua langkah diatas, perlu dilakukan kegiatan 'restorasi' yang merupakan suatu kegiatan yang berupaya meminimalkan peluang spesies invasif masuk ke dalam ekosistem perairan. Agar keseluruhan langkah ini berkesinambungan dan berkelanjutan dibutuhkan penguatan kelembagaan dari pihak pemerintah, swasta maupun swadaya masyarakat; serta peraturan perundang-undangan yang pemberlakuannya dikawal secara bersama.

\section{SIMPULAN}

Kehadiran ikan asing invasif pada suatu ekosistem perairan, akan merugikan ekosistem perairan dalam dua hal, yaitu: (1) sebagai pesaing relung makanan dan habitat terhadap ikan asli, bahkan sering terjadi merupakan prodator bagi ikan asli. Karena ikan asing invasif ini menjadi pemangsa ikan asli dan ikan endemik; (2) sebagai inang/pembawa berbagai penyakit yang sebelumnya tidak terdapat dalam ekosistem perairan yang merupakan habitat ikan asli bahkan ikan endemik. Kedua hal ini seringkali mengubah komposisi spesies dan struktur komunitas ikan, mendominasi dan menyingkirkan ikan asli dan ikan endemik. Untuk menangani adanya ikan asing invasif ini serta menjadi keberlanjutan biodiversitas perairan, diperlukan langkah-langkah sebagai berikut: (1) pencegahan, melalui tahapan penyamaan persepsi dari semua pemangku kebijakan, pelaku kegiatan perikanan, dan masyarakat perikanan tentang diperlukannya sisi pencegahan; dan (2) pengendalian, melalui tahapan identikasi ikan infasif, menjalankan SOP dengan tahapan pengendalian menggunakan pilihan pengendalian kimiawi, mekanik dan hayati; silanjutkan dengan penyingkiran, restorasi didukung penguatan kelembagaan dan peraturan perundang-undangan.

\section{DAFTAR PUSTAKA}

Allen GR, PJ Unmack, RK Hadiaty. 2008. Two new spesies of rainbowfishes (Melanotaenia: Melanotaeniidae), from Western New Guinea (Papua Barat Province, Indonesia). Aqua. Int. J. Ichthyol, 14(4): 209-224

Allen GR, MV Erdmann, CL Dudgeon. 2013. Hemiscyllium halmahera, a new spesies of bamboo shark (Hemiscyllidae) from Indonesia. Aqua. International Journal of Ichthyology, 19(3): 123-136

Anonimus. 2016. Keputusan Menteri Kelautan dan Perikanan Republik Indonesia Nomor KEP.58/MEN/2016 Tentang Status Area Tidak Bebas Penyakit Ikan 
Karantina di Wilayah Republik Indonesia. Jakarta: Kementerian Kelautan dan Perikanan

Anonimus, 2017. Stasiun KIPM Kelas I Yogyakarta. 2017. Laporan Tahunan Stasiun KIPM Kelas I Yogyakarta Tahun Anggaran 2016.

Arai T, MJ Miller, K Tsukamoto. 2013. Larval duration of the tropical eel Anguilla celebesensis from Indonesian and Philipipine coastal. Marine Ecology Progress Series, 251: 255-261, 2003

Diani AF. 2013. Analisis kekerabatan strain lele (Clarias spp.) menggunakan penanda genetik berbasis RAPD-PCR. repository.unpad.ac.id

Froese R, Pauly D. 2018. FishBase. World Wide Web electronic publication. www.fishbase.org, version

Fukumoto S, A Ushimaru, T Minamoto. 2015. A basin-scale application of environmental DNA assesment for rare endemic spesies and closely related exotic spesies in rivers: a case study of giant salamanders in Japan. Journal of Applied Ecology, 52: 358-365

Giacalone VM, G D'anna, F Badalamenti, C Pipitone. 2010. Weight-length relationships and condition factor trends for thirty-eight fish spesies in trawled and untrawled areas off the coast of northernSicily (central Mediterranean Sea). Journal of Applied Ichthyology, 26(6): 954957

Hoffman GL. 2011. Myxobolus cerebralis, a woldwide cause of salmonid whirling disease.Jounal of Aquatis Animal Health, pages 30-37. published online 09 Jan 2011

Jusmaldi, Solihin DD, Affandi R, Rahardjo MF, Gustiano R. 2017. Kematangan gonad dan tipe pemijahan ikan lais, Ompok miostoma (Vaillant, 1902) di Sungai Mahakan Kalimantan Timur. Jurnal Iktologi Indonesia, 17(2):201-213

Kartamihardja ES. 2012. Stoch enhancement in Indonesian lake and resevoirs fisheries. Ind.Fish.Res.J, 18(2): 91-100

Kottelat M, AJ Whitten, SN Katikasari, S Wirjoatmojdjo. 1993. Ikan air tawar Indonesia bagian Barat dan Sulawesi. Periplus Edition (HK) Ltd bekerjasama dengan Proyek EMDI, Kantor Menteri Negara Kependudukan dan Lingkungan Hidup Republik Indonesia, Jakarta. 293 hal.

Mamangkey JJ, SH Nasution. 2012. Reproduksi ikan endemik butini 
(Glossogobius matanensis Weber 1913) berdasarkan kedalaman dan waktu di Danau Towuti, Sulawesi Selatan. Jurnal Biologi Indonesia, $8(1): 31-43$

Muchlisin ZA, M Musman, MN Siti Azizah. 2010. Length-weight relationships and contion factors of two threatened fishes, Rasbosa tawarensis and Poropuntius tawarensis, endemic to Lake Laut Tawar, Aceh. Journal of Applied Ichthiology, 26(6): 949-953

Mulyani Y, A Purwanto, I Nurruhwati. 2011. Perbandingan beberapa metode isolasi DNA untuk deteksi dini KOI Herpes Virus (KHV) pada ikan mas (Cyprinus carpio L.) Jurnal.unpad.ac.id: 1-16

Nasution SH. 2008. Ekobiologi dan dinamika stok sebagai dasar pengelolaan ikan endemik bontibonti (Paratherina striata Aurich) di Danau Towuti, Suawesi Selatan. Disertasi. Sekolah Pascasarjana Institut Pertanian Bogor. 152 hal.

Nielsen JG, W Schwarzhans, RH Hadiaty. 2009. A blind, new spesies of Diancistrus (Teleostei, Bythitidae) from three caves on Muna Island Southeast of Sulawesi Indonesia.Cybium, 33(3):241-245

Nur B, B Hias. 2011. Studi domestikasi dan pemijahan ikan pelangi kurumoi (Melanotaenia parva). Prosiding Forum Nasional Pemacuan Sumber Daya Ikan III, 2011

Pelicice FM, JRS Vitule, DP Lima Junior, ML Orsi, AA Agostinho. 2012. A serious new threat to Brazilian freshwater ecosystems: the naturalization of nonnative fish by decree. Conservation Letters, 7(1): $55-60$

Rahardjo MF. 2016. Ikan endemik Danau Poso. Masyarakat Iktiologi Indonesia, http://iktiologiindonesia.org

Sanches FHC, CA Miyai, TM Costa, RA Cristofoletti, GL Volpato, RE Barreto. 2012. Aggressiveness overcomes body-size effects in fights stages between invasive and native fish spesies with overlapping niches. PloS ONE, 2(1): 1-5

Simanjuntak $\mathrm{CPH}, \mathrm{MF}$ Rahardjo, S Sukimin. 2017. Iktiofauna rawa banjiran Sungai Kampar Kiri. Jurnal Iktiologi Indonesia, 6(2): 99-109

Sukmono T, DS Solihin, MF Rahardjo, R Affandi. 2013. Iktiofauna di perairan hutan tropis dataran rendah, Hutan Harapan Jambi. Jurnal Iktiologi Indonesia, 13(2): 161-174

Syafei LS. 2017. Keanekaragaman Hayati dan Konservasi Ikan Air 
Tawar. Jurnal Penyuluhan

Perikanan dan Kelautan, 11(1): 51-

66

Wirjoatmodjo S. Sulistiono, MF Rahardjo,

IS Suwelo, RK Hadiati. 2003.

Ecological distribution of edndemic

fish spesies in spesies Lake Poso

and Malili Complex, Sulawesi

Island. Funded by Asean Regional

Center of Biodeversity

Conservation and the European

Comission. $30 \mathrm{p}$. 